\title{
THE FAUNA OF TRISTAN DA CUNHA
}

\author{
By H. F. I. EцLiotT
}

This summary is based on observations in the period January, 1950, to October, 1952, during which all the islands of the group have been visited and first-hand knowledge of nearly all known species has been acquired. Control and protection under legal sanction (Wild Animal Protection Ordinance) have been applied for the first time and the results are assessed below. Information based on data supplied by the islanders, so often ignored in the past, has been found to be generally reliable.

1. Wild Cat (Felis catus).--Sporadic over the whole of the main island, no doubt originating in domestic stock. While known to kill numbers of rats, is also responsible for much damage to birds and capable of killing even well-grown mollymauk chicks. There is reason to believe that wild cats are much less common than formerly. Islanders have been encouraged to kill them on sight (normally with aid of dogs) and a reward might well be considered if satisfactory differentiation from domestic animals could be secured.

2. WILD Gont (Capra hircus).-Derived from domestic stock let loose by garrison about 1945. Usually seen on N.W. of main island at about 3,000 feet. Damage to trees reliably reported. Numbers uncertain, probably still less than thirty. Classified as a pest and reward of $10 \mathrm{~s}$. a "tail" offered. Seven killed to date by shooting.

3. Black Rat (Rattus rattus).-An unmitigated pest spread over all the main island from shore to peak to the detriment of crops, birds and stores. The regressive white-bellied form is about as common as the dark grey form. Both can subsist quite easily on wild plants. Doubtful whether even with unlimited labour and funds could now be exterminated.

4. Mouse (Mus musculus).- Theory that rats have exterminated mice on Tristan is untrue. There are still plenty in the settlement area. Norwegians are said to have identified two species. Sufficiently controlled by cats and mousetraps. Occurs on Gough Island and perhaps Inaccessible-probably harmless.

5. FUR-Seal (Arctocephalus pusillus).-Increasing. Quite frequently reported on Tristan beaches. Has recently returned to Nightingale, October to January, at least 90 being counted in November, 1951. Presumed to be spreading from west side of Inaccessible, where there are breeding caves which have not 
been molested for many years. Was found to be numerous in February on all suitable beaches of Gough Island (including unweaned calves), though opinions differed whether total numbers could be reckoned in hundreds or thousands (the windswept S.W. shore which is likely to be favoured was scarcely visited).

Islanders have been in habit of killing all they come across regardless of age or sex, though without going out of their way to do so. Skins roughly prepared used to be bartered on ships but in recent years have been more easily disposed of to nonislander residents or fishing vessel crews for an average of $£ 1$ each. It has been by no means easy to bring these activities under control, especially when ships visit Gough. However, by keeping the species absolutely protected on Inaccessible and Tristan, but being lenient with permits to take reasonable numbers on the other islands while making as sure as possible that the 5s. per skin fee is paid by recipients (easy enough in the case of residents who must peg the skins out to dry), fair measure of control and co-operation from all has been achieved. Prohibition of the entry of sealskins to South Africa (though often eluded) has helped and in the last two years certainly less than a third of the numbers known to have hauled out on Nightingale has been slaughtered.

6. Leopard Seal (Hydrurga leptonyx).- - Large spotted seals of fierce disposition are said to have been met with very occasionally at Cave Point and elsewhere and may perhaps be leopard seals or weddell seals (Leptonychotes weddelli).

7. Elephant Seal (Mirounga leonina).-Formally bred on Tristan (Down-by-the-Pot) and Inaccessible and still does so commonly on Gough. Becoming steadily more numerous and the sight of specimens usually young ones hauled out on Tristan beaches, even those immediately adjacent to the Settlement, is becoming an almost everyday occurrence. This is probably due to the fact that the islanders, who no longer have any use for them, have at last ceased wantonly to destroy any met with and are content merely to tease them (throwing stones into their gaping jaws, etc.). In the circumstances is only likely to require any special protection if it begins to breed again on Tristan.

8. Right Whale (Balaena australis).-Becoming increasingly numerous and almost a pest. At least a hundred round Tristan and Nightingale in 1951. Appears in July off Settlement beaches, reaches a peak in October and leaves again in December. Small 
calves fairly frequent. Unmolested by islanders except for an occasional pot-shot with a rifle from the shore, but regarded as something of a danger to small boats which usually take rapid avoiding action if a whale surfaces near by, though only one instance of an actual collision is recorded, when Sidney Glass was thrown overboard on to a whale's back but apart from laceration by barnacles was none the worse for the experience. Loss of crawfish nets due to whales is quite often reported.

9. Rorqual (Balaenoptera sp.).- "Finbacks", presumably some species of rorqual, are very occasionally sighted, usually between the islands, and are avoided carefully.

10. SEA Lion sp.? A "hair seal", pale coloured, was killed on Big Beach about forty years ago.

\section{Birds}

Note: The nomenclature of Sclater's Systema avium aethiopicarum is used.

1. Macaroni Penguin (Eudyptes chrysolophus).-A stray penguin of this species was shot on Inaccessible on 3rd March, 1938.

2. Rock-Hopper Penguin (Eudyptes cristatus)._-"Pinnamin." Common and increasing breeding species on all the islands. Arrives mid-August, lays from second week September, young fledged by early March, last moulting birds away to sea by midApril. Some protection needed on Tristan though rookeries at Sandy Point, Trypot, Stony Beach, etc., are steadily recovering from the years of exploitation for lamp oil and "tossel-mats" (small and quite useless fancy table mats made from scalps and head plumes) which has now come to an end. As each pair of penguins usually lays three eggs but rears only one chick, time has probably come when controlled exploitation of larger Tristan rookeries based on taking one or two eggs of each clutch could be encouraged and permitted. This might help eliminate the waste of time involved in combining collection of molly and penguin eggs on Nightingale (former laid 10th September and latter getting later each year and now averaging 21 st September). Meanwhile the $\mathbf{1 2 , 5 0 0}$ eggs taken yearly on Nightingale (no permit required) appears to have no effect on the gradual expansion of the rookeries there. The only other active form of exploitation-the plucking of moulting birds for featherpillows, etc.- has no effect. $\mathbf{A}$ few dozen birds are also killed annually for use as fishing bait. 1s. per skin or egg charge to collectors. 
3. Jackass Pengurn (Spheniscus demersus).-Penguins with white stripes on side of head, presumably this species, have been very occasionally seen at Stony Beach, etc.

4. Wilson's Petrel (Oceanites oceanicus).-Occurs regularly at sea off all the islands at most times of year, but no evidence that its presence, e.g. at Gough in late February, indicates local breeding. No charge to collectors.

5. Grey-Backed Storm Petrel (Garrodia nereis).-_" Littlest skipjack." Only at Gough, where no doubt breeding though no nest yet found (in moult February). 1s. per skin or egg to collectors.

6. White-Faced Storm-Petrel (Pelagodroma marina)."White-faced Skipjack." Extremely numerous feeding in kelp round main island from August to December and birds in breeding condition are frequently killed in the village by cats in September to October, so presumably still breeding somewhere on Tristan (though no nests found in recent years), as well as on Nightingale, etc., where birds are occasionally found in burrows. Not noted at Gough. 1s. per skin or egg charge to collectors.

7. White-Bellied Storm-Petrel (Fregetta grallaria)."White-bellied Skipjack." Fairly common round all the islands. Certainly still breeds on Inaccessible, Nightingale and commonly, Gough, probably in December though only bird taken from a burrow $I$ have seen was on Nightingale in April. 1s. per skin or egg charge to collectors.

8. Black-bellied Storm-Petrel (Fregetta tropica).-Vaguely recorded in literature from Tristan, but probably in error unless it has since become extinct. None seen during the last three years.

9. Dusky Shearwater (Puffinus assimilis).-."Whistler." Occurs not very commonly round all the islands; known to breed on Nightingale in small numbers, probably rather more common on Inaccessible and no doubt still numerous on Gough. Almost certainly a very early breeder, laying August/September, birds being in full courtship on Inaccessible in May and none being seen at Gough in February. Collectors should be discouraged from taking too many specimens, though only the usual $1 s$. is charged for a permit per skin or egg.

10. Greater Shearwater (Puffinus gravis).- "Petrel." Breed in large numbers on Nightingale and its neighbouring islets (estimated at anything from three-quarters of a million to two or three million pairs), in increasing numbers on Inaccessible 
(perhaps a quarter of a million pairs) and apparently only lately on Gough. Small numbers which bred a few years at Anchorstock, Tristan, were killed off, but fresh attempts at colonization may be expected any day. Arrives early September, lays second

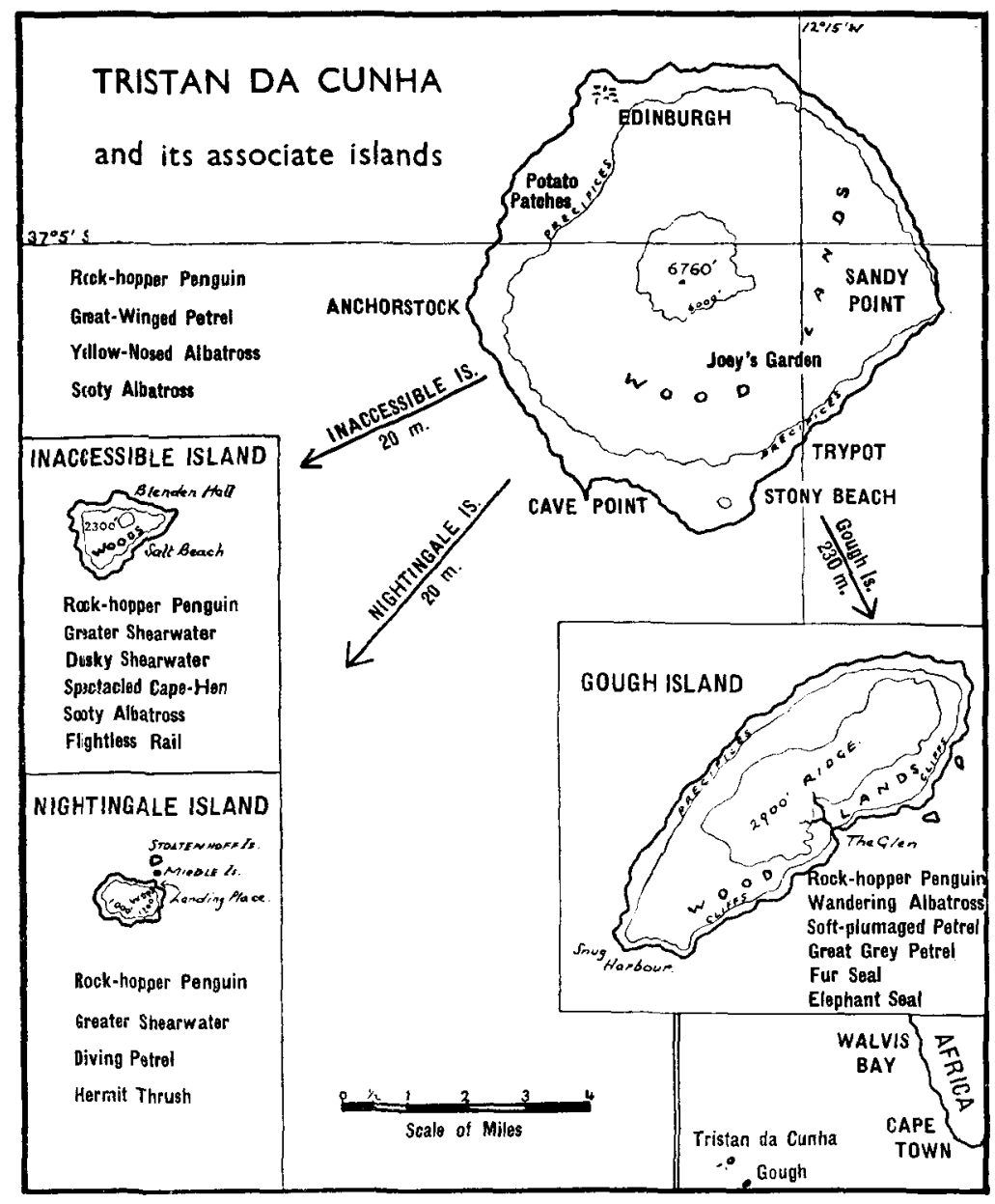

week November, old birds leave by carly April, last fledged young leave end May.

The main food bird of Islanders. Egg trip to Nightingale in November accounts for about 15,000 eggs (many of which are picked off open ground where birds unable to find burrowing 
space have "dumped" them), but this trip has not infrequently been given up in recent years because of the counter attraction of fishing. Fat trip in March/April accounts for a further 15,000 to 20,000 young birds rendered down for fat, though a proportion of the carcases are also salted and some of the feathers saved as fertilizer. This trip is hard and messy work, often prolonged by bad weather, and could probably be eliminated gradually if a cheap cooking fat could be supplied. Moderate numbers of adult birds are eaten or salted incidentally on other trips to the smaller islands.

Owing to the large and increasing numbers of these shearwaters, which are quite unaffected by the exploitations described, an open general permit has been issued, the only condition of which is that a rough count should be kept by the man in charge of each trip. The usual $1 s$. charge is levied to collectors. Protection would be necessary at first if breeding spreads to Tristan, as if a good stock could be built up for local fowling, much time could be saved without reducing food supplies.

11. Great Grey Perrel (Adamastor cinereus).- " Pediunker." Scarce breeding species Tristan. No evidence that it still breeds Nightingale (where formerly recorded) or Inaccessiblepossibly pushed out by Greater Shearwater. Probably still breeds in good numbers on Gough. Lays rather irregularly March to June, young fly August/September. Formerly persecuted for eggs and young birds, is now generally left alone as being too scarce to bother about, but a few well known and easily accessible nests (one above Red Fall near Settlement has been occupied for seventeen years) are probably still robbed illegally. Collectors permits given sparingly at usual $1 s$. charge. This species still needs careful nursing if it is to recover its former abundance and before it can be safely "farmed" for young birds.

12. White-chinned Petrel or Cape Hen (Procellaria aequinoctialis).-- "Ring-eye." About one hundred pairs, of what has proved to be a definite "spectacled" subspecies, breed in scattered colonies on the plateau of Inaccessible and keep in vicinity of that island most of the year. Laying October. Good eating but islanders have been asked to leave alone and I think do so. Permits to collect-at usual $1 s$. fee-should be issued sparingly.

13. Great-winged Petrel (Pterodroma macroptera)."Black Haglet." Increasing as a breeding species on Tristan where formerly very common but nearly exterminated. Lays in June/July, last young leave very early November. In 1951 
adjudged sufficiently numerous again to allow limited exploitation, under permit, of young birds for food : 125 taken. If numbers show no decline this can safely be continued as nests are scattered all over island. No evidence that any now breed at Nightingale where formerly recorded (probably pushed out by Greater Shearwater) or at Inaccessible ; may do so at Gough but this has never been proved. 1s. charge to collectors.

14. Schlegel's Petrel (Pterodroma incerta)._-“"Largest White-breasted Haglet." Very like previous species in size, voice and habits. Breeds sparingly on Tristan, laying in June/ July. Islanders have been asked to leave alone but as burrows are indistinguishable from previous species a few young find their way into the pot under "Black Haglet " permits. May also be increasing, as observed coming in at dusk at Sandy Point in fair numbers, but collectors' permits should at present be issued sparingly. 1s. per egg or skin. Not known from the other islands.

15. Soft-plumaged Petrel (Pterodroma mollis)._-"Whistler," "Nighthawk" or " Littlest White-breasted Haglet." Scarce breeding species competing with Greater Shearwater on Nightingale and Inaccessible, but very numerous indeed on Gough, though decimated by skuas. What seems to be a rather darker form of the same species breeds sparingly on Tristan about the $2,000 \mathrm{ft}$. level. Lays October/November. Too small to interest islanders as food. Permits to collectors at $1 s$. rate.

16. Kerguelen Petrel (Pterodroma brevirostris).- "Blue Nighthawk." A wholly dark grey burrowing petrel, which seems identical with this sub-antarctic zone petrel better known from Kerguelen and Marion, has been twice recorded at the main island and found breeding commonly on Gough (downy young in February). Permits $1 s$.

17. White-necked Petrel (Pterodroma externa).-A specimen (or specimens) assigned to this species and described as a new race by Mathews was apparently secured on the main island more than thirty years ago, but nothing resembling it has been noticed in recent years.

18. Pintado Petrel or Cape Pigeon (Daption capense).-Occurs off Tristan in winter. No fee or permit for collecting.

19. Broad-billed Whale-bird or Prion (Pachyptila vittata). - Nightbird." Common breeding species on all the islands, badly harried by skuas. Lays in August. On Tristan main breeding place is sea-washed cave under Hill-Piece and it is customary to rob the accessible ledges of eggs for food, about 
sixty a year being thus collected. No objection if covered by permit, so that record can be kept. Not molested elsewhere. Fee to collectors $1 s$.

20. Blue Petrel (Halobaena caerulea).-A " blue petrel" has been reported on several occasions either aboard the fishing vessels or captured in the vicinity of Round Hill, Inaccessible. It seems very unlikely but just possible it will turn out to be this species, but is more probably identical with No. 16 above.

21. Grant PETrel (Macronectes giganteus).-- "Stinker" or "Nellie". Formerly bred on Tristan but deserted after extinction of breeding elephant seals in Stony Beach area. Now regular winter visitor. Still breeds on Gough. $1 s$. fee to collectors.

22. Common Diving Petrei (Pelecanoides urinatrix)."Flying Pinnamin." Breeding species on Nightingale (upwards one hundred pairs) and Gough, not identified as such elsewhere. Permits to collectors should be sparing-usual $1 s$. fee. Lays in September.

23. Wandering Albatross (Diomedea exulans).- "Gony." Not more than half a dozen breeding pairs on Inaccessible, still numerous on Gough. Lays January/February, fledged young fly in November. Occasional birds alight on Tristan where once common and it may re-establish itself if carefully guarded. Now left alone by islanders, but "fishing" for Albatross from Company's vessels, especially at Gough and by coloured fishermen, needs checking. Fee to collectors for skin or egg from Inaccessible $£ 2$, but should be issued sparingly if at all. Elsewhere $1 s$.

24. Black-Browed Albatross (Thalassarche melanophris).-"Cape Molly." Fairly common winter visitor off-shore. No fee or permit to collectors.

25. Yellow-nosed Albatross or Mollymauk (Thalassarche chlororhynchus).- "Molly." Greatly increasing on Tristan as breeding species, very numerous Nightingale, rather more sparse on Inaccessible and Gough. Lays early September, young fly by end of April. One of the islanders' most important food birds, but nearly exterminated on Tristan by taking of too many eggs and adults. There are now at least 2,000 pairs on Tristan and if exploitation is confined to taking of young birds under permit, Joey's Garden area being kept as a reserve, numbers should continue to increase. Eggs to the number of about 2,500 are still taken on Nightingale on the September "egg trip" under general open licence, but it is beginning to be realized that the chicks are better value as food. These are taken and salted to 
the number of about 1,700 to 2,000 , mainly on the "fat trip ". The main thing is to kecp a careful check on numbers taken and make sure any decrease is balanced by more stringent control. Permits to collectors $1 s$.

26. Sooty Albatross (Phoebetria fusca)._-"Peeoo." Increasing on Tristan as breeding species, numerous on Inaccessible and Gough, a few pairs on Nightingale. Lays September/ October, young fly by end of May. Almost equally sought after by the islanders for food as the "molly," but tends to nest in more inaccessible places. The eggs are now left alone. About half the estimated 1,500 pairs nesting on Tristan had the nearly fledged young birds taken under permit in 1952. Open general licence for other islands, but taking birds on Nightingale discouraged. Permit to collectors $1 s$. per egg or skin.

27. Frigate-BIRd (Fregata sp.).-Occasional visitor, twice seen by the writer chasing terns, but not yet secured or identified.

28. Great White Heron (Casmerodius sp.).- Large heron on Nightingale in April, 1950, possibly again at Inaccessible April, 1952.

29. Snowy Egret (Leucophoyx thula).-Stray shot on Tristan 5th May, 1952.

30. Cattre Egret (Bubulcus sp.).-Parties of small white herons feeding among cattle reported by islanders as having very occasionally visited Tristan.

31. Duck Family (Anatidae).-A small flight of ducks about six or eight in number visited the main island several years ago probably in November and haunted the ponds around Pig Bite. One or two were shot and from the description given by the islanders would appear to have been some species of teal.

32. Inaccessible Island Flightless Rail (Atlantisia rogersi)._- " Island Cock." Confined to Inaccessible where perhaps ten to twenty thousand pairs spread all over the island but more thickly in coastal strips. Breeds in November. Much sought after by collectors and although it is doubtful whether in the terrain of Inaccessible even the most wholesale collecting would effect its extinction, permits are issued as sparingly as possible at a fee of $5 s$. per skin or clutch of eggs.

33. American Gallinule (Ionornis martinica).-_"Guttersnake." Regular if presumably stray visitor March to July, once November, frequenting watercourses and flax gardens of village, also Sandy Point. No doubt usually killed by cats, small boys, etc., otherwise might conceivably settle down to breed, though specimens in anything approaching adult breeding plumage are rare. $1 s$. to collectors. 
34. Gough Island Coot (Porphyriornis comeri).-" Big Island Cock." Common on Gough especially along valleys and in coastal strips. Breeds November/December. Only requires protection from collectors, so fee of $5 s$. per skin or clutch is charged, though no danger of extinction.

35. Tristan Coot (Porphyriornis nesiotis)._- "Tristan Island Cock." Practically indistinguishable from previous species except by colour of feet. Not remembered by any living person and undoubtedly extinct, probably through the agency of rats.

36. South American Dotrerel (Zonibyx modesta).--One was shot on 16th May, 1952.

37. Siberian Pectoral Sandpiper (Erolia acuminata).A sandpiper of this unexpected species was shot on 16th June, 1950.

38. American Spotted Sandpiper (Actitis macularia).--One shot on Little Beach 5th February, 1952.

39. Bartram's Sandpiper (Bartramia longicauda).- One shot in Settlement on 19th October, 1952.

40. Southern Black-Backed or Kelp Gull (Larus dominicanus).- Stated in the literature to have been a breeding species but is certainly not one now and only represented by stray immature birds in some winters, e.g. 1952. No fee or permit to collectors.

41. Southern Skua (Catharacta antarctica).-_"Sea Hen." Common on all the islands-breeding species-(possibly a number of distinct races are present during winter) and though quite a useful scavenger is classed as a pest owing to its depredations on domestic fowls and all kinds of young sea-birds. Lays September/October. No protection given or required and no fee or permit to collectors.

42. Swallow-Tamled Tern (Sterna vittata).-" King Bird." Common breeding resident cliffs of all the islands, laying December. Fee to collectors $1 s$. per skin or egg.

43. Common Noddy (Anous stolidus).-" Woodpigeon." Common breeding visitor on cliffs of all the islands, arriving September, laying November/December, departing April. Fee to collectors $1 s$.

44. White-Capped Noddy (Megalopterus minutus)._-“ Treenesting Woodpigeon." Reported to have bred Inaccessible (January) and possibly Tristan but not identified in recent years and record may be an error due to unusual choice of breeding site by common noddy.

45. TERN (Sterna sp.).-A rather large grey and speckled 
tern was reported frequently feeding on caterpillars of pastures and patches during May and June, 1952.

46. Tristan Thrush (Nesocichla eremita eremita).—“"Starchy." Probably only a few hundred pairs scattered thinly over main island except round settlement. No doubt kept severely in check by rats and cats. Would be useful predator on potato grub but needs tree cover near patches. Fully protected; permits to collectors issued sparingly at $£ 2$ per skin or egg.

47. INACCESSIBLe Island ThrUSir (Nesocichla eremita gordoni)._- "Starchy." Common on Inaccessible-larger and more aggressive than Tristan race. $1 s$. fee to collectors.

48. Nightingale Island Thrush (Nesocichla eremita subsp.). - "Starchy." Undescribed race-still larger, darker, and more rufous than either of the others. Very numerous indeed. Lays in September. 1s. fee to collectors.

49. American Chimney Swallow (Hirundo rustica erythrogaster).-Occasionally seen. One shot on 22nd March, 1938, and another on 30th October, 1952.

50. Tristan Bunting (Nesospiza acunhae acunhae)."Canary." Extinct on Tristan. Common breeding species on Inaccessible (said to be identical with Tristan bird though this is not really probable). $1 s$. per skin or clutch to collectors.

51. Nightingale Island Bunting (Nesospiza acunhae questi). —"Canary." Very common breeding species on Nightingale. Lays November to January. $1 s$. to collectors.

52. Wilkins' Bunting (Nesospiza wilkinsi wilkinsi).—“Bigbeaked Canary." About thirty to forty pairs in woodland on Nightingale. A somewhat vulnerable species which islanders have been requested to treat with special care. Permits to collectors given very sparingly, 22 per skin or clutch. Lays January/February.

53. Dunne's Bunting (Nesospiza zwilkinsi dunnei)._-"Bigbeaked Canary." Discovered and named by Norwegian expedition. Sparse in bigger and thicker woods of Inaccessible. Collectors should not be allowed to over-exploit. $£ 2$ fee per skin or clutch.

54. Gough Island Bunting (Rowettia goughensis).—“Gough Canary." Common breeding species on Gough Island. Not dependent on woods and could not be easily brought to extinction. $1 s$. each to collectors.

\section{Summary}

The Faunal List of Tristan is thus so far as at present known made up as follows :- 


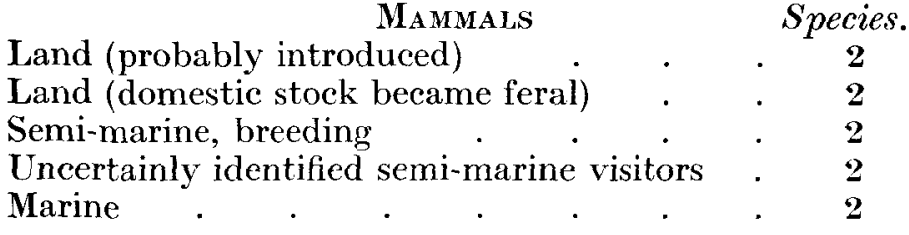

Total . . . 10

Breeding species

Birds

Regular visitors

Strays

Uncertainly identified strays

Status uncertain or very doubtful records . 4

Extinct . . . . . . . . . $\quad$. 1

Total . . . . 54

For a small group of islands inhabited by people of European stock for over 125 years, the record of only one species rendered extinct (and that survived by an almost indistinguishable cousin) is better than average and should be easily maintained provided-

(a) the idea of properly "farming" birds is firmly inculcated into the islanders. Abstention from exploitation of scarcer species should be easy so long as the adequate provisioning of the island can be maintained. The few species now exploited are in such numbers that their use for food on the present or in some cases even a gradually increasing scale is without objection from a conservation point of view, so long as true and exact records are kept so that any tendency to decrease can be immediately noticed and counterbalanced. Hence it has been constantly reiterated to the islanders that it does not so much matter if a man takes a bird without a permit or exceeds the number allowed on a permit, so long as he reports the fact or discrepancy immediately so that records remain accurate. This policy has resulted in a much improved position over the last year or so. Previously when hunting was forbidden or strictly limited, an unspecified quantity of birds and eggs was taken with little or no chance of the culprits being discovered. Now, under a fairly liberal policy with permits and, in the case of the main island, keeping only the far south-eastern segment as a total reserve, it would be possible, if for example the number of young sooty albatross 
showed a sharp decline, to introduce with active public co-operation a restricted quota, extend the reserved area, or even apply a total ban, until the stock recovers. That the stock can and does recover rapidly under protection has been amply demonstrated in recent years.

(b) The second proviso is the successful control of the activities of collectors. There is a strong demand for Tristan specimens, especially from America where some museums are willing to pay as much as 40 dollars for rare species. However much one may deplore the commercialization of scientific study, one cannot ignore this factor. Another thing which has to be taken into account on Tristan is that the "gift" to a non-islander of a rare bird or egg has long been a customary gambit in the game of obliging him or her to give something in return. Fortunately conservation is assisted by the fact that any specimens leaving the island by post have to be declared under parcel-post regulations, while in a small community so fond of gossip it is difficult for any resident non-islander to receive a specimen without the fact becoming widely known. The loophole is of course the personnel of fishing vessels and passing ships.

In trying to secure effective control, therefore, the policy has been to ensure that the non-islander takes out a permit (even after the bird has been collected) and pays the fees. The latter, though generally small, have the effect of making a present of a bird skin or egg unacceptable to anyone who is not really interested. A useful ally in conservation is also the fact that only one islander-Joe Repetto--has taken the trouble to learn how to skin and sex a bird correctly, and the non-islander collector who $i s$ interested in the bird, either for scientific study or for sale, must therefore either rely on this man's services or do the job himself. In either event it is comparatively easy to make sure that the collection is covered by permit and under control. In conclusion one may add that in the terrain and conditions of Tristan and in the light of the measure of protection described in these notes, the only species the survival of which gives much cause for anxiety is the largebilled bunting of Nightingale and Inaccessible, dependent as it is for existence on the not very extensive woodlands of those islands. A considerable acreage of wood on Nightingale was recently destroyed in a single violent gale and, though regeneration of Phylica nitida is fortunately rapid, supplies of the seec of this tree, which is the main food of the big bunting, must temporarily be quite seriously reduced. 